\title{
Doing it 'ourselves': Civic initiative and self-governance in spatial planning
}

\begin{abstract}
In this paper, an analysis of civic initiatives to collectively realise a particular community ambition amongst informal settlers in a Ghanaian metropolitan area is presented. This community ambition is grounded in collective intent with no government or city authority intervention. Using secondary data review and interviews conducted in two selected neighbourhoods in the Accra Metropolitan Area, the findings show that self-governance mechanism has the potential to support informal settlers' capacity in terms of adapting to changing environmental situations by mutual cooperation and consensus building. The paper recommends a relook of planners' role in spatial planning in Ghana, emphasising a shift from development decision making to actors and facilitators of socio-spatial initiatives by community residents. This changing role may lead to the suppression of the negatives and maximisation of the positives of self-governed initiatives for the benefit of society.
\end{abstract}

Key words: Self-governance; informal settlements; spatial planning; Accra Metropolitan Area; community networks; civil society; actor networks

\section{Introduction}

The last few years have witnessed a remarkable shift in both planning theory and practice (Allmendinger, 2009). Fundamentally, this shift involved the growing awareness of a world beyond planners control: a non-linear world. Here, planners no longer seek certainty, they instead act as advocates and facilitators for actors involved in the planning process (De Roo, 2010). Similarly, governments and policy makers have emphasised the need to encourage self-organising civic initiatives of communities to supplement the services provided by the welfare state (Boonstra, 2015; Boonstra \& Boolens, 2011; Nederhand et al. 2014). This signifies a move towards self-governance in spatial planning. Civic initiatives - also conceptualised as bottom-up development or grass-root initiatives (Miazzo \& Kee, 2014; Newman et al. 2014) - involve the active engagement between citizens and nongovernmental actors in making decisions to serve specific community interest beyond the spheres of ongoing public policy. 
Essential to understanding spatial planning and self-governance is the realisation that the former (i.e. government policy initiatives) represents a manifestation of a 'planned intention' guided by formal rules whilst the latter (i.e. civic initiative) is a 'collective action'led by actors (e.g., individuals, communities, non-governmental organisations) guided by some form of internal coordination in informal structures. Though both are purposeful and geared towards achieving commonly agreed goals, in self-governance, actors enjoy a high degree of freedom in shaping the system within which they exist based on their preferences (see Rauws, 2016; De Roo, 2015).

An emerging view amongst urban theorists and researchers is that effective functioning of urban areas should embrace uncertainties, multiple possible alternative futures and flexible decisions (Albrechts, 2006; De Roo, 2010; Korah et al., 2017; Rauws et al. 2014) and further allows for self-organisation and self-governance (see Alfasi \& Portugali, 2007; De Roo, 2016; Nunbogu \& Korah, 2016; Korah et al., 2016; Rauws et al. 2016; Rauws, 2016; Boonstra, 2015). Self-governed civic initiatives in spatial planning require urgent attention particularly in Africa and other developing countries where in Roy's (2005) view, most of the major urban transformations of the $21^{\text {st }}$ century are likely to occur. Additionally, much of the ongoing and expected urbanisation would be happening in African cities (Cohen, 2006), with African urbanisation labelled as the fastest in the world (Ichimura, 2003), although this position is hotly contested (see Obeng-Odoom, 2010; Potts 2009, 2012). The rate of Africa's urbanisation is expected to trigger complex spatial processes (e.g. cityregions and civic initiatives), which challenge traditional urban governance strategies (Agyemang et al. 2017). Although self-governance has manifested in several developed counties and fields, for example, in fisheries cooperatives (Townsend, 1995), farmer cooperatives (Termeer et al. 2013), management of forest resources by local communities (Ostrom, 2005), management of green spaces (Mattijssen et al. 2017) and management of urban greeneries (Buizer et al. 2015; Lawrence et al. 2013), it is as yet limitedly appreciated in the spatial planning field in Africa and other developing countries. Self-organised civic initiatives have not received spatial planners' attention and not part of mainstream planning in African cities.

In this contribution, the paper aims to make a case for civic initiatives in urban development and how spatial planners in developing countries of Africa, particularly Ghana should embrace these initiatives to generate wider and multiple benefits for society. Using empirical data from the Greater Accra Metropolitan Area of Ghana, this paper 
discusses how civic initiatives can transform urban areas, and the implications for urban governance. The paper is structured into five sections. Section 2 presents literature review on the concept of self-governance in spatial planning. Section 3 describes the research setting and methods used. Section 4 presents the case analysis and discussion of the case. In Section 5, the paper concludes with some recommendation to improve spatial planning and urban governance in Ghana, and other developing countries.

\section{Self-governance, Social Intelligence, and Spatial Strategies}

\subsection{Changing relations between government and citizens: From 'command and control' towards self-governance}

More often there are tradeoffs between normative planning approach that outlines idealised stages to be followed, and the 'real world', which is often messy and less straight forward (Allmendinger, 2009). With the reality that planning issues are increasingly becoming complex and more unpredictable, planning approaches which move away from the desire to achieve predefined outcomes are gaining attention in literature. There is a burden on planners to 'make sense' of the everyday life and activities in space and act as 'transition managers' by suppressing, guiding or even triggering these activities to achieve a desired intent (De Roo, 2010; Korah et al. 2016). This is more so because with limited budget and fiscal resources available to city authorities especially in developing countries, there is gradually a fundamental shift from redistribution towards a philosophy of self-help (see Bailey \& Pill, 2011). This changing role of the state can be regarded as a transition, often referred to as a shift from government to governance (Kooiman \& van Vliet, 1993).

Although this shift has been described in various ways, most accounts underline the fading importance of the government as the epicenter of society (Ansell, 2000; Büchs, 2009; Salamon, 2001). According to Beck (1994), decision-making about societal development is no longer solely in the hands of government, but actors such as companies, scientists, the media, new social movements and the citizenry. Teubner (2011) argues that in a contemporary society, no social sub-system, not even politics, can represent the whole society. The transition to governance manifests in citizens and communities possessing greater control and freedom in taking initiatives for their welfare. As discussed in Section 1 , self-governance processes are revelatory in several ways such as fisheries cooperatives (Townsend, 1995), farmer cooperatives (Termeer et al. 2013) among others. In the context of urban development, self-governance has been mainly related to street refurbishment 
initiatives, co-housing projects, and water and sanitation infrastructure development (Boonstra, 2015; Miazzo \& Kee, 2014; Nunbogu \& Korah, 2016).

Self-governance, as used in this paper, refers to the freedom with which individuals and communities undertake initiatives and coordinate their actions for accomplishing the objectives of these initiatives (Kooiman, 2003; Arnouts et al. 2012). Individuals and communities thus have a high degree of freedom in shaping a system they are part of. According to De Roo (2016), self-governance is intended and, in fact, a general term for the processes of self-regulation and self-management. Self-regulation is deliberate and with intent, starting with a joint initiative and with actions in support of this initiative. Here, spatial interventions are mainly driven by actors in a form of actor-networks, cooperatives or associations. This covers the emergence of urban development out of coordinated and collective actions by multiple actors (see Nunbogu \& Korah, 2016). Self-governance and citizens' initiatives are receiving attention and recognition in several countries because they are believed to make society stronger by getting more people working together and putting more power and responsibility into the hands of groups, networks, neighborhoods and local communities.

There are, however, instances of professionals (e.g. planners) finding it difficult to engage with citizens' initiatives adequately (Boonstra, 2015; van Dam et al. 2014). When citizens start putting their ideas and ideals into practice, they organise things in their own way, which may oppose formal plans. More importantly, and in relation to the nature of citizens' initiatives in the urban area, Alberti and Waddell (2000) argue that the urban spatial configuration results from a collective and aggregate order through numerous locally made decisions involving many intelligent and adaptive agents. The behaviours of these agents are subject to changing their rules of action based upon new information. This is true for many neighbourhoods in cities of the Global South where informality is dominant (see Roy, 2005). For instance, urban land in Maputo (Mozambique), is physically structured and planned by urban dwellers aspiring to establish legitimate and viable forms of socioculturally informed physical order (Andersen et al. 2015a; 2015b) and in Ghana, individuals dictate the pace of urban development based on local conditions and discretions rather than the state (Yeboah \& Shaw, 2013). The foregoing analysis highlights the challenges of self-governance (e.g. the plurality of civic initiatives and potential contradictions with formal national policy agenda). In this regard, governments have a role in protecting the 
boundary of self-governance, which is described variously as 'framing' and 'enabling, facilitating and encouraging diversity in styles of organising' (Healey, 2006, p. 289). In other accounts, this role of government in self-governance is termed as coproduction (Albrechts, 2012; Ostrom, 1996; Watson, 2014). Coproduction aims to combine the provision of public goods/services needed and the empowerment of mutually supportive communities that could influence policy to meet their needs (Abrechts, 2012). This role of governments, according to Albrechts (2012), involves changing the perceptions and the approach of many professionals (public and private) about how plans, policies and public services are conceived and delivered, with the objective of enabling the change needed in an open and equitable way.

However, despite the growing importance of self-governance, its application is limited in the milieu of spatial planning and development in Africa and particularly Ghana. This situation has arisen because self-governance is barely understood by planners and not captured in the planners' modalities (e.g., zoning, development control) for delivering planning services. For instance, even though slums in many cities in Africa form sociospatial neigbourhoods, which constitute face-to-face interaction, identity and a common understanding of joint challenges and objectives, these neighbourhoods are often marginalised and overlooked in terms of spatial planning and land-use rights (see Cobbinah, 2017; Parnell and Pieterse, 2010). Naturally, in this case, spontaneous civic initiatives and individual ambitions dedicate the pace and configuration of development in cities (Nunbogu \& Korah, 2016; Yeboah \& Shaw, 2013). Unfortunately, but true, this situation makes 'official plans' obsolete even before their implementation.

\subsection{Citizens' initiatives and organisation, cooperation and bonding processes}

In the global governance context, active citizen participation and individual responsibility have gained intellectual currency (Boonstra \& Boelens, 2012; Nunbogu \& Korah, 2016; Rauws, 2016). In this paper, citizen initiatives involve the collective ambition amongst individuals to jointly realise a particular urban transformation. These initiatives are usually in response to a trigger (e.g. housing shortages, forced eviction threats) and are interwoven with ethical principles and social relationships (Rauws, 2016; Van Dam et al. 2014). Individuals link their political and social aims to 'the project of their own live' and direct the project towards a flourishing lifestyle (see Giddens, 1991). 
'Do-it-yourself initiatives are motivated by collective intent and often participants make agreement on the way forward. Within this context, there is always some degree of coordination among the participants which defines the organising process in citizen initiatives. The organisational forces are the rules of the game which individuals use to structure and organise their behaviour and interaction with one another (North, 2005; Rauws, 2016; Boonstra \& Boelens, 2011). In discussing hybrid governance, Borgen and Hegrenes (2005) identify four coordinating mechanisms in organisations: Handbook, handshake, Invisible hand, and visible hand. This paper adapted and discussed two relevant mechanisms: handbook and handshake which symbolise formal and informal coordination in citizen initiatives respectively. Handshake refers to informal code of conducts based on trust, norms and values of actors. This has dialectical relationship with organsiation, giving shape to it, whilst being reproduced by repeated rounds of customary behaviour (Pelling \& High, 2005). Handshake mechanism works in non-hierarchical organisation where there is enhanced motivation and a strong sense of 'oneness'. The handbook coordinating mechanism is the explicit formal rules, restrictions and instructions driven by the selfinterest of individuals. Coordination exists in myriad social relationships and is normalised through and contingent on social context.

Coleman (1990) describes social capital as a by-product of social networks and support systems amongst individuals, family or community members. Literature on social networks (Gitell \& Vidal, 1998; Szreter \& Woolcock, 2004) differentiates three types of social capital: bonding, bridging and linking. Bonding social capital refers to trusting cooperative relationships amongst members of a network who are similar in terms of social identity whilst bridging social capital deals with relationships amongst people who are more unalike in socio-economic status, race/ethnicity and power. Szreter and Woolcock (2004) expanded on the above distinction and linked social capital: the interactions between individual groups and other institutions which are superior in power and can constraint activities of the groups, such as the relationship between government and citizens. The linking social capital enables people to leverage resources, ideas and information from formal institutions and further provides a platform for negotiation.

\subsection{Analytical framework for self-governance in spatial planning practice}

In this paper, self-governance in spatial planning is treated as citizens' initiatives to collectively realise an ambition in the urban area. A group of citizens might organise themselves to initiate a course of action in their neighbourhood in order to improve: social 
amenity, ensure social cohesion, and/or to protest/prevent force eviction among others. Such actions consist of an organised set of activities (Schatzki, 2002) and are linked to certain ethical principles, rules and social relationships which provide meaning to the practice (Giddens, 1984; Rauws, 2016; Van Dam et al., 2014).

In recognition of this, and in order to analyse self-governance in planning practice, the paper uses an analytical framework influenced by the Policy Arrangement Approach [PAA] (Arts \& Leroy, 2006). The PAA is defined as "the temporary stabilisation of the content and organisation of a particular policy domain" (Van Tatenhove et al. 2000, p. 54). Here the interactions between policy actors are assumed to gradually develop into more or less stable patterns. The PAA helps to analyse and understand change and stability within policy arrangements by defining the policy/initiative at stake, the actors involved, and the written and unwritten rules governing their behaviour (Liefferink, 2006). The PAA has recently been employed in several self-governance studies albeit not in spatial planning (e.g. Buizer et al. 2015; Lawrence et al. 2013; Van der Jagt et al. 2016). The PAA distinguishes the following four analytical dimensions that can be employed to study governance (Liefferink, 2006):

1. The actors and their coalitions involved in the policy domain;

2. The division of resources between these actors, leading to differences in power and influence, where power refers to the mobilisation and deployment of the available resources, and influence as to who determines policy outcomes and how;

3.The rules of the game currently in operation, in terms of formal procedures of decision making and implementation as well as informal rules and 'routines' of interaction; and

4. The current policy discourses, where discourses entail the views and narratives of the actors involved (norms, values, definitions of problems and approaches to solutions).

The PAA, originally developed to study policy arrangements, rather than governance practices - lacks an explicit focus on what actors actually do in the field in order to achieve their aims (Ayana et al. 2015). In this paper, there is focus on societal activities in order to understand how these relate to self-governance in urban transformation. To address this, the line of argument of Mattijssen et al. (2017) was followed to add a fifth dimension to 
the analytical framework: activities. Activities, in the context, refer to the actions undertaken by actors in order to realise the intents of self-governance. Thus, five dimensions: discourses, actors, resources, rules, and activities, are employed in this paper to analyse citizen initiatives in the study area.

\section{Research Setting and Methodology}

\subsection{Research Setting}

Accra is the capital of, and largest city in Ghana with a population growth rate of $4.2 \%$ between 2000 and 2010 (Ghana Statistical Service [GSS], 2010). The city has a population of about 1,848,614 (GSS, 2010) which constitutes $46.1 \%$ of the total population of Greater Accra region, one of the ten administrative regions of Ghana. Geographically, Accra has the coordinates of $5.6037^{\circ} \mathrm{N}, 0.1870^{\circ} \mathrm{W}$ (see Figure 1). The primacy of the city has influenced the inflows and outflows of humans. Migrants constitute about $60.3 \%$ of Accra's population (GSS, 2010). A key challenge confronting the city is inadequate housing especially among low-income households (Owusu, 2011; GSS, 2014). This situation has arisen due to, among others, the dominance phenomenon of planning chasing spatial development in Accra which has resulted in the development of informal settlements across the city (UN-HABITAT, 2009; Nunbogu, 2014).

\subsection{Approach and Methods}

This study is based on a research conducted in 2014 on civic initiatives in informal settlements in the Greater Accra Metropolitan Area. Data on recent urban trajectory in Accra (2017) has been added. The study approach is a case study (Yin, 1994). A review of relevant literature on civic initiatives, self-governance and planning was undertaken at two levels: global and local. The global review focused on research works on actor networks, self-governance and civic initiatives in spatial planning, whilst local level review focused on documents on urban development dynamics in Ghana which basically includes metropolitan planning reports, socio-demographic reports on cities and urban planning reports and academic articles on Ghana (e.g. GSS, 2000; 2010; 2014; UN-HABITAT, 2009). The review of literature contributed to understanding the local urban dynamics in Accra and to identify major stakeholders involved in development planning and management of the city. The output from this informed the selection of Old Fadama and Amui Dzor as case study neighbourhoods for the study, and the agencies to be interviewed. The selection of these neighbourhoods was informed by their unique characteristic as slum 
communities, and are faced with several consistent eviction threats (Nunbogu, 2014; UNHABITAT, 2009).

Semi-structured interviews were conducted with two officials from two agencies responsible for human settlement planning and urban functionality in Accra. These agencies are: the Town and Country Planning Department (TCPD) responsible for spatial planning and zoning; and Accra Metropolitan Assembly (AMA) responsible for the physical and socio-economic development of Accra. In addition, semi-structured interview conversations were conducted with Peoples Dialogue on Human Settlements - a local non-governmental organization which advocates social infrastructure and women economic/livelihood empowerment in urban informal settlements, and the Ghana Federation for the Urban Poor (GHAFUP). At the community level, in depth interviews were conducted with four leaders of the Slum Union of Ghana, 3 executives of Amui Dzor housing cooperative, and six opinion leaders (4 males and 2 females) who represent the various settlements. This composition created an opportunity to solicit the views of both male and female leaders. The purpose of these interviews was to ensure varied and multiple opinions on self-governance and the emergence of civic initiatives in the study area. The interview data were analysed using NVIVO 10 qualitative research analysis software. This software was used to identify key themes from the interviews including the predevelopment of civic initiatives; actors; and activities involved these initiatives. Being an explorative study, it is important to understand the processes of self-governance within the selected communities from the perspective of the settlers and institutions, as they are the key actors.

\section{Results and Discussion}

The results of the two case study communities are presented differently to highlight their differences and similarities. First, the findings on the Old Fadama community are presented. Second, the results on Amui Dzor are presented. The discussion section draws on the findings of both communities and analyses them within the framework of available literature, highlighting on the contributions of this study and areas requiring future studies.

\subsubsection{Slum Union of Ghana in Old Fadama as a civic initiative}

Old Fadama is one of the city's most deprived but innovative slums (see Figure 1). It evolved as a temporary living settlement for people from the north of Ghana fleeing ethnic conflicts (i.e. the Nanumba-Konkomba ethnic conflicts) in the 1980s (Grant, 2006). The 
community occupies about 31.3 hectares of land and it is estimated to be home to about 80,000 people (MacPherson, 2012). Since it is not officially planned as a residential area, the community does not receive any form of state supplied social facilities (King \& Amponsah, 2012). However, Old Fadama continues to expand with the construction of makeshift structures mostly wooden housing structures in dump sites (AMA, 2007). The area occupied by the squatters is public land acquired by the Government of Ghana under executive instrument the 'Accra Industrial Estate (Acquisition of lands) Ordinance No. 28 (1956)', by which part of the land was assigned to light industrial activities, including 'food processing', 'auto repairs' and a brewery (Grant 2006, p.9). Colonial and post-colonial governments undertook activities to reclaim usable land from the swampy lagoon environment through dredging and in-filling to enhance the flow of the Odaw River area (Grant, 2006). The land that was left unused after the dredging and reclamation activity has become the occupation of the squatters. The local economy of Old Fadama is informal with a mix of commercial and industrial activities. The Slum Union of Ghana is a demonstration of the self-organisation capacity of informal settlers to dialogue with government institutions.

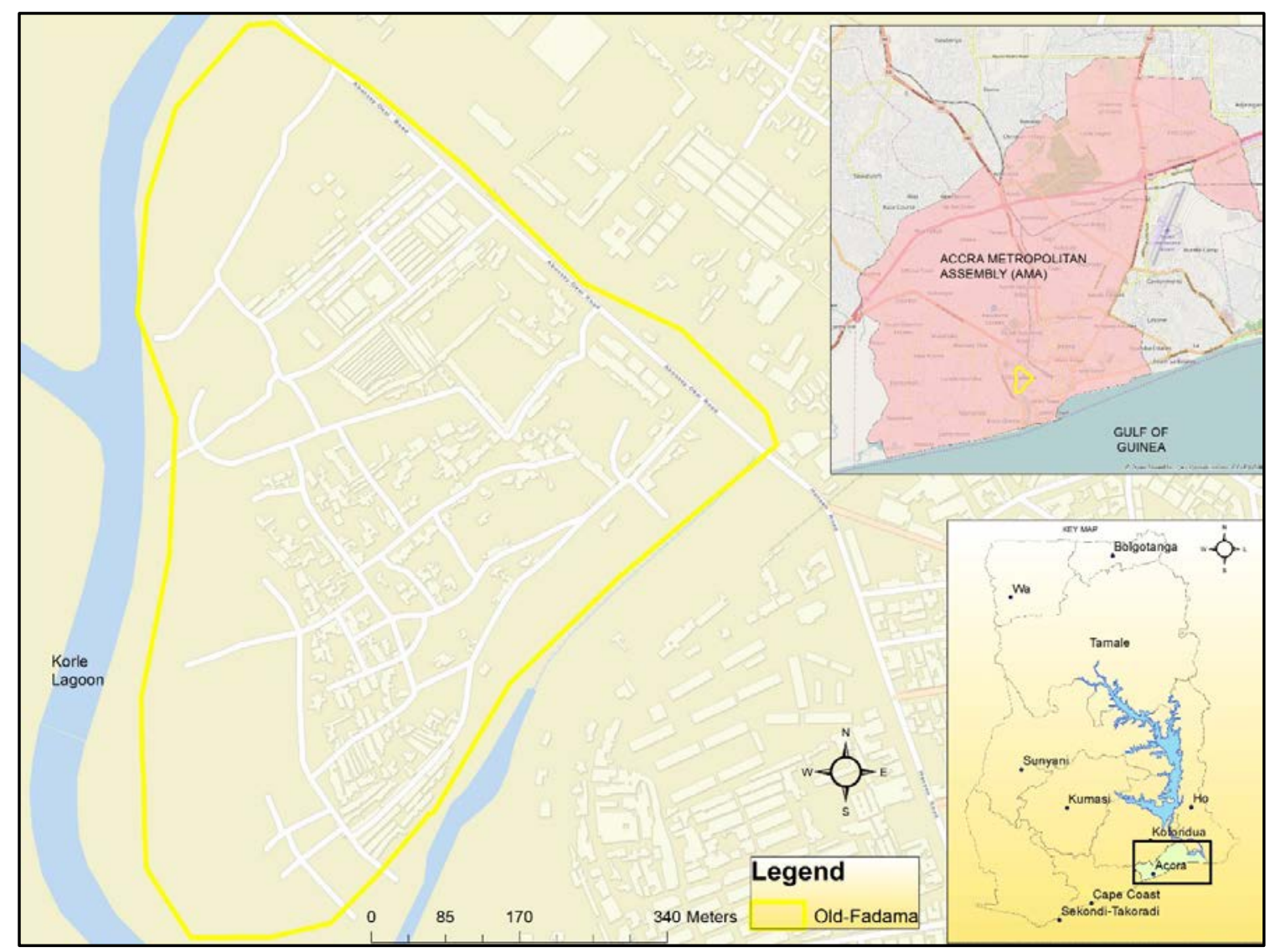

Figure 1: Geographic location of Accra and Old Fadama 


\section{History and Discourse on Civic Initiatives in Old Fadama}

Findings from the agency interviews indicate that civic initiative in Old Fadama began in 1993 when residents observed that squatting on government lands incites serious trouble. The fear of eviction triggered the evolution of some strategies to safeguard their welfare. Instead of calling for a general community meeting, the community residents organised themselves into savings group to first promote social cohesion among the women and between the various clans and ethnic groups in the community. At this stage, the community realised that through stronger social cohesion and united front, they can demand for their rights from government authorities. Therefore, the initiative gained the support of the men and was disseminated to other sections of the community.

\section{Resources for civic initiatives in Old Fadama}

Interview conversations with the community opinion leaders revealed that access to land, financial resources and social capital was important precondition for the success of their civic initiatives. The formation of a savings group enabled the pooling of financial resources, constituting the basic capital for the women. After few years of cooperating and pooling financial resources, residents appointed leaders whose responsibility was to coordinate the saving groups and also mediate in conflicts within the community. By the year 1998, Old Fadama (hereinafter OA) settlements had developed a robust social and political hierarchy, but these frameworks were not legal in the eyes of governmental institutions. The residents made use of their local political party affiliations and religious allegiance with politicians to restrain government eviction threat in 2002 (see UNHABITAT, 2005; Grant, 2006).

\section{Local Driven Activities by Old Fadama Residents}

The community undertook several activities in order to realise their ambition. First was the election of leader. Elected leaders represented the community to deal with external organizations and exerted much influence such as liaising with police in criminal searches in the community. Also, since their union was not legally registered, some government institutions disregarded them and their actions were referred to as nuisance and against public order. With the support of community members, the leadership hired an office space. In June 2012, representatives from other slums were invited to a general meeting to form a union which was later registered under the Attorney's General Department as 'Slum Union of Ghana' (See Kumah, 2012). According to the President of the Union, the union 
undertakes four (4) main activities. These include lobbying with government to end forced evictions and fulfill their responsibilities to slum communities; rapid response to emergencies such as fire outbreaks and floods in slums; educating and sensitising slum dwellers on their rights and responsibilities; and attracting social amenities to slum communities.

\section{Actors in Civic Initiative in Old Fadama}

Interviews with the executives of People Dialogue on Human Settlement, GHAFUP, and leaders of the slum union revealed that efforts at the local level linked the community to several organisations such as the Centre for Public Interest Law (CEPIL), Shack/Slum Dwellers International (SDI) and People's Dialogue on Human Settlements (PDS). In 2002, OA collaborated with CEPIL to appeal a court action against them and other informal settlements. The court action by the residents of $\mathrm{OA}$ restrained force eviction in their settlement and the other informal settlements. The community connection with NGOs enabled it to jump scales and explored other opportunities. Working with SDI, a savings model was developed which sought to further develop community solidarity. It linked the urban poor across ethnic, religious, national and international boundaries. This later became a learning experience and facilitated connection with slum dwellers internationally. The community achieved a lot of success through the interaction with NGOs. These include;

i. They were able to restraint eviction; through their actions and networking with NGOs and other slum dwellers, leaders were able to challenge and demonstrate to government demanding their human rights. Also, the residents highlighted the absence of national policy to deal with spatial quality, the marginalised and urban poor. Drawing the attention of UNDP, the Ministry of Works and Housing was instructed to include slum inventory survey in its action plans and annual reports (see Grant, 2006).

ii. Local-local and local-global connection; the leadership of OA engaged in several crosssection and cross-cultural activities. Representatives visited South-Africa, India, Thailand and Kenya in exchange programmes. This deepened their understanding on community-led initiatives and they learned about the benefits of cross-sectional and cross-cultural integration. It also opened the settlement to the global world (the 
external environment) and thus created an opportunity to learn from its external environment and share with its neighbours or other informal settlements.

iii. Development of cordial relationship with Government, self-governance at the grassroot level enabled the residents to enjoy a greater degree of legitimacy when dealing with policy makers. Government then shifted from its stand of force eviction to one that involves dialogue with community members. The cordial relationship between government and residents of OA triggered several collaborative initiatives in the community. In 2013, Accra Metropolitan Assembly (AMA) and constituents of OA collaborated in dredging the Korle lagoon. On this project, the community joined forces and collectively agreed to demolish some makeshift houses which were 5 metres from the banks of the lagoon. Also, they community collectively took the initiative to extend the scope of the project by discouraging residents from dumping refuse and defecating in the lagoon. Though AMA monitored the project to ensure that the set conditions were met, the community coordinated the actual execution of the project.

iv. Community upgrading: this initiative was realised through the integration of several activities. Prior to this phase of the initiative development, OA was regarded as the worst slum in Ghana in terms of access to social infrastructure and the settlement design. Fire outbreak was also common. However, because there were no access routes it was impossible for fire tenders to go into the community to fight fire. The community leadership therefore decided to create access roads within the community to improve accessibility. Actors in the social hierarchy were fundamental to this development because there were some inhabitants who objected the initiative especially those whose structures were affected. In dealing with this group, the community collectively conducted several meetings and agreed to relocate the affected households. Structures were rearranged and several access routes were created. In addition to the access routes, the community constructed gutters to enhance drainage in the settlement during rains. They also collectively designated some areas within the community as sanitary areas. This action was geared towards reducing the menace of indiscriminate refuse disposal in the community. These actions were generally applauded and residents were proud of their collective efforts in reshaping their settlement. For instance, in a discussion a community member said: 
"we were seen as thieves in the eyes of the government. But the activities of Philip and his people (executives of the Union) opened our eyes and put us on our feet to demand our rights and liberate ourselves from harassment. We now know what to do in case of emergencies, and we have created pathways for vehicles and gutters for water to flow in our settlement. We have planned and managed our community better" (OA, 04.2014).

The above statement clearly indicates the collective intent, commitment and readiness of community members to protect their 'city'.

\section{Rules Governing Civic Initiative in Old Fadama}

According to the executives of the slum union, the community members adopted several mechanisms in order to stabilize the initiative. The organising process of the initiative was one of institutionalizing modes of internal and external cooperation. Internally, the community elected leaders to facilitate, coordinate and administer the daily activities of the group. The interaction and interrelation between the residents of $\mathrm{OA}$ also initiated the formulation of byelaws to guide the actions of members in the savings group. For instance, it was stipulated that every member of a savings group had to deposit her money (2 Ghana Cedis - less than US\$ 1) before OA market day (which falls on every Saturday) and members who failed to pay the fixed amount was fined to pay three times the amount. In order to make the union a legal entity and also formalised their interactions with government agencies, community leadership drafted a constitution to adopt some code of ethics and later registered the union under the Attorneys General Department.

\subsubsection{Amui Dzor social housing project as a civic initiative}

Amui Dzor is a slum community located at the Ashaiman Municipality, which is close to Tema, the industrial hub of the country (see Figure 2). Tema was planned as the industrial city of Ghana. During its development, many of the workers who came to work at various construction sites and the harbour at Tema were living at Ashaiman. Ashaiman therefore served as the dormitory town. Waste wood from the harbour construction sites were used to construct temporary dwelling units by the immigrants. Over the years these wooden structures never got changed and became permanent housing units. This makes the Ashaiman municipality one of the few in the country with about $70 \%$ of its settlements being informal (King \& Amponsah 2012). The social housing project of Amui Dzor 
reveals the essence of partnership between informal dwellers and urban development stakeholders in addressing basic social problems.

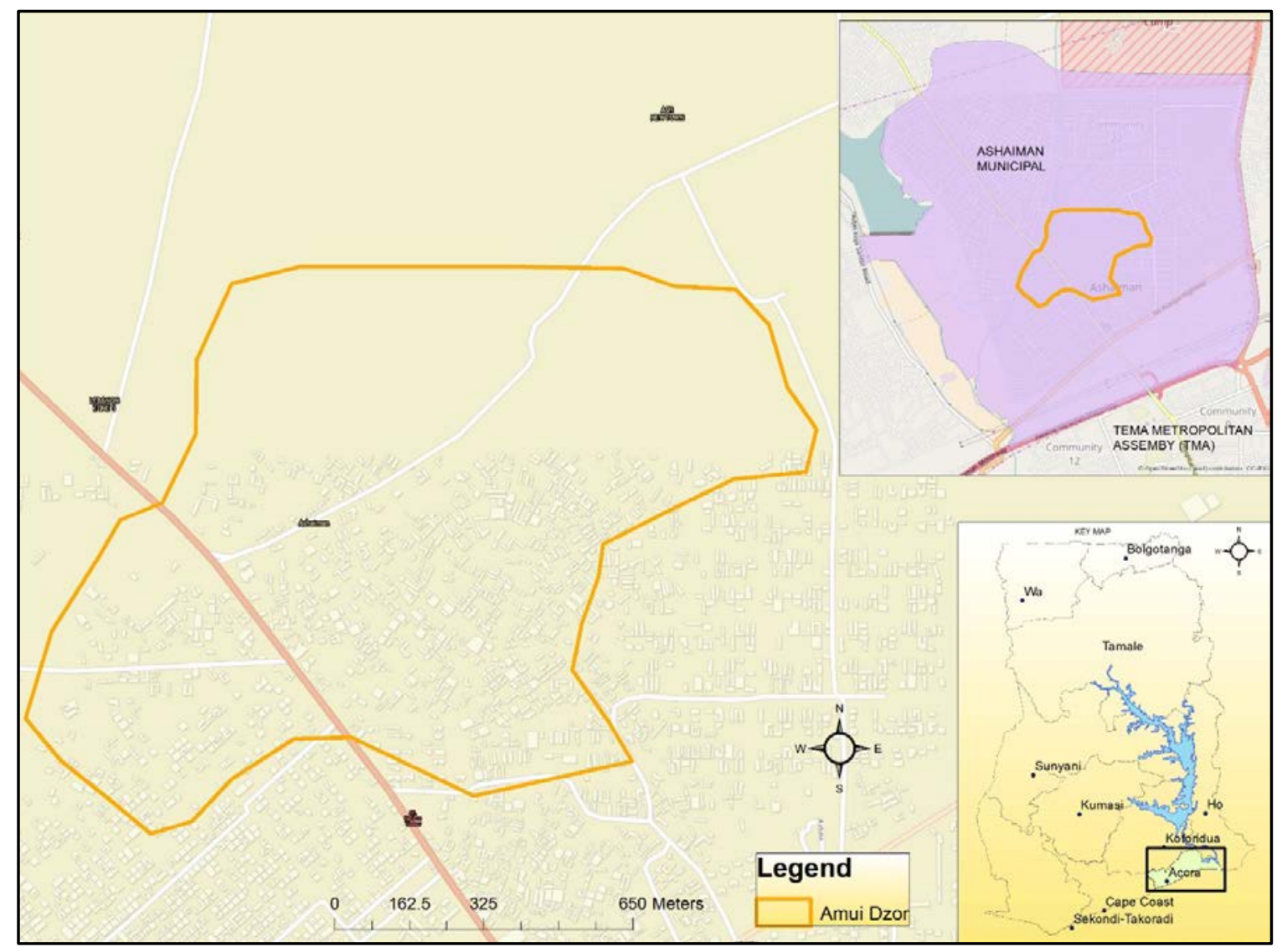

Figure 2: Geographic location of Amui Dzor

\section{History and Discourse on Civic Initiative in Amui Dzor}

Discussions with the executives of Amui Dzor housing cooperative showed that the initiative began in 2004, when some women who wanted to lessen their economic plight mobilised themselves into savings group. The objective was to establish a savings group that would enable them save money and manage their finances. As an open system, the community exchanged and absorbed information from its external environment. The women groups absorbed ideas and experience through informal interaction and visits to Old Fadama - the other case - which had a better experience as far as micro savings is concern. They save daily, mobilising not only financial resources but also ideas on pressing issues in the community and strategies for addressing them. By June 2005, the group registered 2000 members and formed a savings cooperative. In 2006, the community increased their savings and opened a savings account with Ghana Commercial Bank where they save weekly. This served as collateral for them to access loans. Through regular 
meetings, dialoguing and deliberations, the group identified a problem - inadequate housing. Among others, the group formed the Amui Dzor housing cooperative, which sets out plans and strategies to invest their savings in a social housing project - the initiative.

\section{Resources for Civic Initiative in Amui Dzor}

According to the cooperative executives, access to land and financial resources was an important precondition for the success of the housing initiative. The formation of a savings group enabled the pooling of financial resources, which formed the basis for accessing a mortgage from Ghana Commercial Bank. The mortgage became the initial source of financing the housing initiative. In addition, some community members provided land for construction of the housing facility.

\section{Civic Initiative Activities in Amui Dzor}

Interviews with cooperative executives and some opinion leaders of Amui Dzor revealed that several activities were undertaken to realise the objective of the initiative. First was the construction of wooden apartment which served as a pilot project (see Figure 3). The cooperative rented out the apartment to interested members and received a lot more profit which was ploughed back into their savings. This pilot project was faced with restrictions from the municipal assembly which prohibited the construction of new structures in the settlement. However, due to the commitment of members, some of them moved to stay with friends and donated their pieces of land for construction. A three-story structure consisting of 15 commercial stores, 1 and 2-bedroom apartments, and a 12-seater public toilet was constructed (Figure 4).

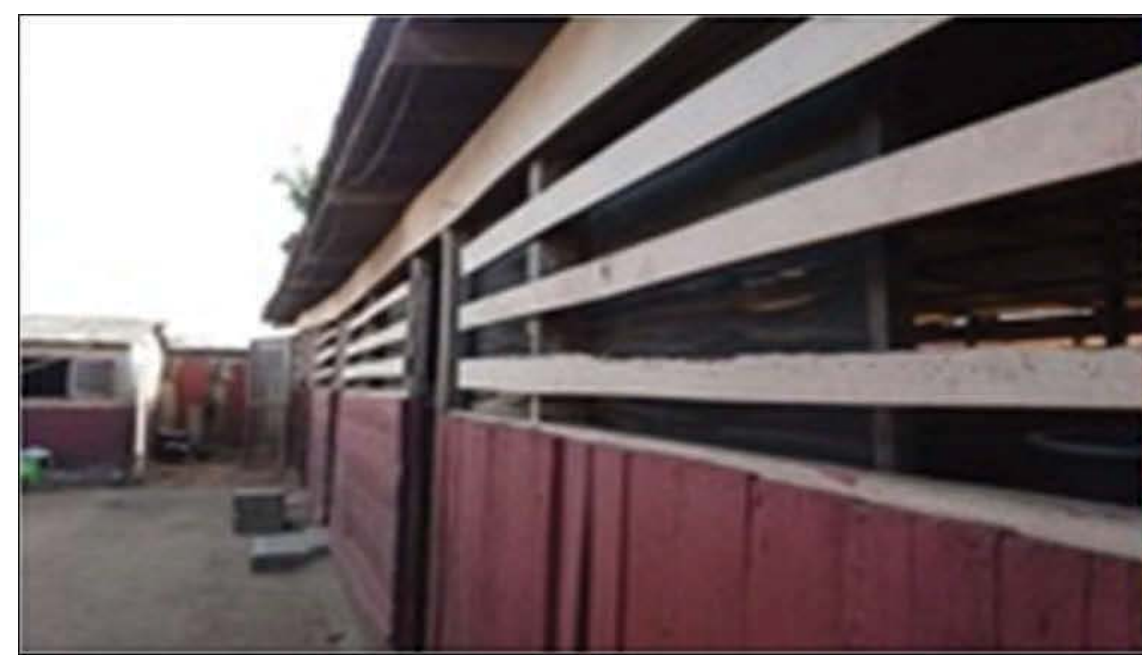

Figure 3. The pilot project (wooden structure)

Source: Field survey, 2014 


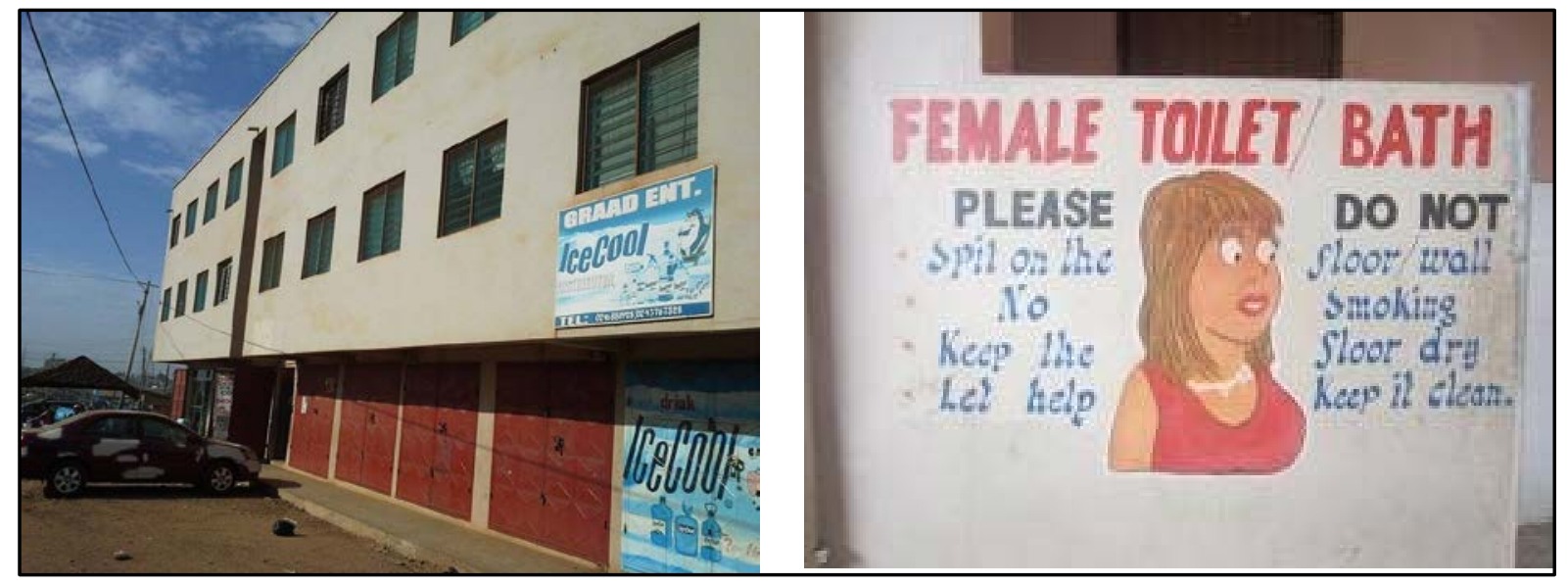

Figure 4: Left: Amui Dzor Housing Project; Right: The Public Toilet at the Amui Dzor Housing Project Source: Field Survey, 2014

\section{Actors involved in Civic Initiative in Amui Dzor}

The initiative had several actors who contributed in one way or the other in ensuring its success. Ghana Federation for Urban Poor (GHAFUP) for example, in 2006, sponsored some members of the cooperative to travel to India for knowledge exchange on social housing. The collective action between the community and GHAFUP facilitated the formation of a partnership with the UN HABITAT Slum Upgrading Facility. Through negotiation with the traditional council of Ashaiman, a piece of land was secured for the project. According to the cooperative executives, Tekton Consultants were partnered to design the structure. Members also negotiated with the municipal assembly for building permit. The assembly readily issued the permit and offered consultancy services since the project was in line with its slum upgrading strategies. After gaining the support of the planning institutions, UN HABITAT helped to secure a long-term mortgage from Ghana Commercial Bank - with which the cooperative has been transacting business - at an interest rate of $12 \%$. Although, the initiative was about 'do it ourselves', the analysis indicates the involvement of a broad range of actors beyond citizens, including government and non-governmental bodies, financial institutions and professionals.

\section{Rules Governing Civic Initiative in Amui Dzor}

From the study, we observed that certain formal and informal arrangements were put in place in order to ensure sustainability of the housing structure and toilet facility. Members were required to pay rent albeit at a reduced cost in accordance with the constitution and rental agreements of the cooperative. Non-residents who use the public toilet were charged 
and the housing cooperative collects this money and uses it to help maintain the facility and also pay back its loans. In order to ensure good sanitary conditions within the housing facility, the cooperative entered into a contractual agreement with the Municipal Waste Management Department (MWMD) to empty the septic tank of the facility within every 5 months and also collect domestic waste daily. It established a 10-year revolving fund which is an essential element for the repayment of the loan secured. Monthly rental payments from the housing units and commercial stores together with revenue generated from the public toilet and the sale of water are ploughed back into this fund, which continues to revolve fund into new businesses of members and also service the loan. It is expected that, the first 3 years would be used to service the loan and the remaining 7 years use to raise capital for the construction of a new housing structures in the community.

\section{2 Discussion}

From the analysis of the cases, it is clear that the 'initiative' at the discourse stage is usually plural and not predefined - keeps evolving (e.g. from savings group to social housing cooperative). This situation could be challenging for spatial planners to deal with because of its complexity (Boonstra, 2015; van Dam et al. 2014). Spatial planners have to follow/monitor these initiatives as they evolve by becoming active participants and contributing to framing the problems and solutions. Even though the Amui Dzor housing project had several actors, there were no formal or written rules governing their behaviour except the contractual agreement with the MWMD. The housing cooperative developed a constitution that guided the actions of members. The constitution was applicable internally and did not apply to external actors. Many of the external actors (e.g. NGOs) interacted with the neighbourhoods without written rules. This means that their actions were based on 'handshake' - refers to informal code of conducts based on trust, norms and values of actors (Pelling \& High, 2005).

In the case of $\mathrm{OA}$, the eviction threats issued to the community changed its structure (unorganised, informal) and function (to mobilise money and promote social cohesion) to a well-organised group advocating and demanding their rights from the government. The residents collectively acted (through power struggles and demonstrations) against the government to protect their 'city'. Their action resulted in the formation of the Slum Union of Ghana (SUG). The people are organised but not in a formal institutional design-in this case, governance was the responsibility of the neighbourhoods, guided by their 
cherished norms and values (handshake) and stipulated rules (handbook). These values and rules make the initiative robust internally and in its position to interact with institutions. Within this context, spatial planners' attention is drawn to the reality that society (informal settlements) is an open system consisting of different parts, interacting and exchanging information with its environment.

The initiative in both cases was triggered by the need to address inadequate infrastructure and social amenities. In the case of $\mathrm{OA}$, it was the need to create access routes and drainage whilst that of Amui Dzor was the need for housing and sanitary facilities. Both cases show that informal communities better understand their problems and challenges, and given the needed support, can address these problems. In both cases, the role of social capital was central (see Coleman, 1990) in ensuring success of the initiatives. All three types of social capital: bonding, bridging, and linking (Gitell \& Vidal, 1998; Szreter \& Woolcock, 2004), were present in the organisation of the communities, and their interaction and relationship with formal institutions. The communities established cooperatives, mobilised resources, negotiated and leveraged resources, ideas and information from formal institutions (both public and private) and government and non-governmental bodies.

Self-governance in spatial development involves a wide range of activities beyond the initiative by the communities. Communities involved in self-governance often pursue several objectives (e.g. physical, social, economic, financial and political) and employ multiple activities. The cases highlight the effectiveness of individuals/neighbourhoods in undertaking initiatives and self-organising themselves to achieve the aims of these initiatives. The community collectively saves money, which served as collateral to secure credit as well as marshalling the collective capacity and commitment required to sustainably manage projects. Partnership between the community and other stakeholders (government and Non-Governmental Organisations) is important for addressing the social dysfunction that has for long excluded the urban poor - particular dwellers of informal settlements from decent and affordable housing and their rights to other basic social amenities.

By applying the Policy Arrangement Approach (PAA) in spatial planning, the study found that it is a useful framework to enable spatial planners in Accra (Ghana) to understand the: 'why' (discourse), 'who' (actors), and 'how' (resources, activities and rules) of civic initiatives in the urban environment. Understanding the dynamics of self-governance offers opportunities for coproduction. The cases compared to similar self-governance 
initiative in a suburb of Groningen, the Netherlands (Rauws, 2016), show similar pattern and dynamics. Both the Ghanaian and Dutch cases show the involvement of municipal authorities in 'do-it-ourselves' initiatives. These authorities play an important role in protecting the boundaries of civic initiatives by supporting or constraining these initiatives as and when necessary.

\section{Conclusion}

The aim of this paper was to make a case for civic initiatives in urban development and how spatial planners in developing countries should deal with these initiatives for the benefit of society. From the cases, the development of civic initiatives is based on collective intent of the community members. Community members' desire for survival necessitated collective actions across different scales to position themselves within the local context. It is worth acknowledging that the civic initiatives did not emerge spontaneously from the daily interactions of actors. Instead, they were self-initiated by the communities who established themselves as a union and explicitly execute collective actions. Although individual ambitions were present especially when the community wanted to create access routes in the case of Old Fadama, these interests were sacrificed in order to propel collective intent. This was possible because of the internal coordination within the community.

The cases demonstrate that self-governance mechanisms have the potential to support a neighbourhood's capacity to adapt to changing circumstances (e.g. ailing/dysfunctioning social amenities and eviction threats). The findings show that informal settlements constitute socio-spatial milieus, which better understand their problems and challenges. These settlements are also better positioned to address these problems, particularly when support is received from the city authorities. This is evident in how OA coordinated and through participation and member-led decision-making process, succeeded in preventing force eviction by the government. The Old Fadama case offers opportunities for an allinclusive spatial and land use planning that recognises and addresses the needs of squatter settlements. Understanding the mechanisms of self-governance may enable spatial planners to be ingrained in processes of self-governance and civic initiatives within the daily environment. In this instance, planners must become actors by establishing meaningful heterogenous relations with other actors, e.g. informal settlers, around any socio-spatial initiative. The focus will be to balance the intents of these actors by 
highlighting the positives and suppressing the negatives of each initiative for the good of society. Planners would also have to provide the conditions necessary for engendering civic and self-governed initiatives in urban transformation. This could for example mean, revising the planning standards in some instances to reflect local conditions and situations as the case maybe.

The case communities developed a cordial relationship with not only the Government but other non-state actors. This presupposes that beyond the ambition to achieve predefined outcomes by public planners and decision makers, community engagement and dialogue should be at the forefront in civic initiatives. It was clear that no spatial plan by AMA could improve motorable accessibility in $\mathrm{OA}$ without resistance. However, through the leadership of OA, and with the support of community members, access routes were created to improve accessibility. In such a situation, it is concluded that self-governance and civic initiatives provide ways to open up command and control planning systems to allow for more diverse urban configurations in African countries, and to increase the opportunities for incorporating anticipated and unanticipated changes during urban development (see also Rauws \& De Roo, 2016).

\section{References}

Accra Metropolitan Assembly (2007). Medium term development plan 2006-2009. Accra, Ghana

Agyemang, F. S. K, Amedzro, K. K., \& Silva, E. (2017). The emergence of city-regions and their implications for contemporary spatial governance: Evidence from Ghana. Cities, 71, 70-79.

Alberti, M \& Waddell, P. (2000). An integrated urban development and ecological simulation model. Integrated Assessment, 1(3), 215-227.

Albrechts, L. (2006). Bridge the Gap: From Spatial Planning to Strategic Projects. European Planning Studies, 14(10), 1487-1500

Albrechts, L. (2012). Reframing strategic spatial planning by using a coproduction perspective. Planning Theory 12(1), 46-63.

Alfasi, N. \& Portugali, J. (2007). Planning rules for a self-planned city. (164-182, Ed.) Planning Theory, 6(2), 164-182

Allmendinger, P. (2009). Planning Theory. London: Palgrave, Mac Millan.

Andersen, J. E., Jenkins, P. \& Nielsen, M. (2015a). Who plans the African city? A case study of Maputo: part 1 - the structural context. IDPR, 37 (3); doi:10.3828/idpr.2015.20.

Andersen, J. E., Jenkins, P. \& Nielsen, M. (2015b). Who plans the African city? A case study of Maputo: part 2 - agency in action. IDPR, 37 (4); doi:10.3828/idpr.2015.25.

Ansell, C. (2000). The networked polity in regional development in western Europe. Governance, 13 (2), 279-291. 
Arnouts, R., van der Zouwen, M. \& Arts, B. (2012). Analysing governance modes and shifts: governance arrangements in Dutch nature policy, Forest Policy and Economics, $16,43-50$.

Arts, B., \& Leroy, P. (2006). Institutional dynamics in environmental governance (Vol. 47, pp. 1 283). Dordrecht: Springer.

Ayana, A. N., Vandenabeele, N., \& Arts, B. (2015). Performance of participatory forest management in Ethiopia: Institutional arrangement versus local practices. Critical Policy Studies, 11(6), 19-38.

Bailey, N. \& Pill, M. (2011). The continuing popularity of the neighbourhood and neighbourhood governance in the transition from the 'big state' to the 'big society' paradigm. Environment and Planning C: Government and Policy, 29, 927- 942: doi:10.1068/c1133r.

Beck, U., (1994). The invention of politics. In U. Beck, A. Giddens, and S. Lash, (Eds). Reflexive modernization: politics, tradition and aesthetics in the modern social order. Cambridge: Polity Press

Boonstra, B. (2015). Planning Strategies in an Age of Active Citizenship; A Post-structuralist Agenda for Self-organization in Spatial Planning. Groningen: InPlanning.

Boonstra, B., \& Boelens, L. (2011). "Self-Organization in Urban Development: Towards a New Perspective on Spatial Planning." Urban Research \& Practice 4 (2): 99-122. doi:10.1080/ 17535069.2011.579767.

Borgen, S.O. \& Hegrenes, A. (2005). How can transaction costs economics add to the under- standing of new contractual formats in the Norwegian agri-food system? Working Paper No. 2005-7. Oslo: Centre For Food Policy, Norwegian Economics Agricultural Economic Research Institute.

Büchs, M., (2009). Examining the interaction between vertical and horizontal dimensions of state transformation. Cambridge journal of regions: economy and society advance, 2 (1), 35-49.

Buizer, M., Elands, B. H. M., Mattijssen, T. J. M., van der Jagt, A., Ambrose-Oji, B., Geroházi, E., \& Santos, E. (2015). The governance of urban green spaces in selected EUcities, p. 97. Copenhagen: University of Copenhagen.

Cobbinah, P. B. (2017). Managing cities and resolving conflicts: Local people's attitudes towards urban planning in Kumasi, Ghana. Land Use Policy, 68, 222231.https://doi.org/10.1016/j.landusepol.2017.07.050

Cohen, B. (2006). Urbanization in developing countries: Current trends, future projections, and key challenges for sustainability. Technology in Society, 28(1-2), 63-80.

Coleman, J. (1990). Foundations of Social Theory, Cambridge, Harvard University Press.

De Roo, G. (2003). Environmental planning in the Netherlands: Too good to be true: From commandand-control planning to shared governance. Ashgate.

De Roo, G. (2010). Planning and Complexity:An introduction. In G. de Roo \&. E.A. Silver (Eds), A Planner's Encounter with Complexity (pp. 1-18). Franham: Ashgate.

De Roo, G. (2016). Self-organization and Spatial Planning: Foundations, challenges, constraints and consequences. In G. de Roo \&. L. Boelens (Eds), Spatial Planning in a Complex Unpredictable World of Change. Groningen: InPlanning.

Foucault, M. (1977). Power and sex: an interview with Michel Foucault.

Giddens, A. (1984). The constitution of society: Outline of the theory of structuration. Cambridge: Polity Press.

Giddens, A. (1991). Modernity and self-identity: Self and society in the late modern age. Stanford university press.

Gitell, R. V. \& Vidal, A. (1998). Community Organizing: Building Social Capital as a Development Strategy, Newbury Park, Sage Publications. 
GSS (2005). 2000 population and housing census, Greater Accra regional analysis, socioeconomic and demographic trends analysis. Analytical report, vol. (1\&2). Accra: GSS.

GSS (2012). 2010 population and housing census: Summary report of final results. Accra, Ghana: Ghana Statistical Service.

GSS (2014). 2010 population and housing census: District analytical report, Accra metropolitan. Accra: Ghana Statistical Service.

Grant, R. (2006). Out of Place? Global Citizens in Local Spaces: A Study of the Informal Settlements in the Korle Lagoon Environs in Accra, Ghana. Urban Forum, 17(1), $1-24$.

UN-HABITAT (2009). The right to adequate housing. Fact Sheet No, 21.

Healey, P. (2006). Collaborative Planning, Second Edition. Shaping Places in Fragmented Societies. Houndmills, Basingstoke: Palgrave Macmillan.

Heylighen, F. (2001). The science of self-organization and adaptivity. The encyclopedia of life support systems, 5(3), 253-280.

Ichimura, M. (2003). Urbanization, Urban Environment and Land Use: Challenges and Opportunities. Asia-Pacific Forum for Environment and Development Expert Meeting. Guilin, People's Republic of China.

Kilduff, M., \& Krackhardt, D. (1994). Bringing the individual back in: A structural analysis of the internal market for reputation in organizations. Academy of management journal, 37(1), 87-108.

King, R. S., \& Amponsah, O. (2012). The role of city authorities in contributing to the development of urban slums in Ghana. Journal of Construction Project Management and Innovation, 2(1), 285-313.

Kooiman, J. (2003). Governing as Governance, London, Sage.

Kooiman, J. \& van Vliet, M. (1993). Governance and public management. In: K. Eliassen and M. van Vliet (eds). Managing public organizations. London: Sage.

Korah, P. I., Cobbinah, P. B., \& Nunbogu, A. M. (2017). Spatial Planning in Ghana: Exploring the Contradictions. Planning Practice \& Research, 1-24. http://dx.doi.org/10.1080/02697459.2017.1378977

Korah, P.I, Cobbinah, P.B, Nunbogu, A.M \& Sarah, G. (2016). Spatial plans and urban development trajectory in Kumasi, Ghana. Geojournal, 1-22: doi: 10.1007/s10708016-9731-1.

Kumah, P. (2012). Demanding the Rights of Slum Dwellers in Old Fadama. Retrived April 20, 2014 from https://philipkumah.wordpress.com

Lawrence, A., De Vreese, R., Johnston, M., Konijnendijk van den Bosch, C. C., \& Sanesi, G. (2013). Urban forest governance: Towards a framework for comparing approaches. Urban Forestry and Urban Greening, 12, 464-473.

Liefferink, D. (2006), The Dynamics of Policy Arrangements: Turning Round the Tetrahedron. In Arts, B., \& Leroy, P. (eds). Institutional dynamics in environmental governance. Dordrecht: Springer.

MacPherson, (2012). Innovations in Affordable Housing: Amui Dzor Housing Project. [Available on] http://www.sdinet.org [Accessed on 23 April, 2014]

Mattijssen, T., Buijs, A., Elands, B., \& Arts, B. (2017). The 'green' and 'self' in green selfgovernance - a study of 264 green space initiatives by citizens. Journal of Environmental Policy \& Planning, 1-18, DOI: 10.1080/1523908X.2017.1322945

Miazzo, F., \& Kee, T. (2014). We Own the City: Enabling Community Practice in Architecture and Urban Planning. Amsterdam: Trancity. 
Nederhand, J., Bekkers, V., \& Voorberg, W. (2016). Self-Organization and the Role of Government: How and why does self-organization evolve in the shadow of hierarchy?. Public Management Review, 18(7), 1063-1084.

Newman, J. (2011). Mobilising the active citizen in the UK Tensions, silences and erasures. In J. Newman and E. Tonkens (eds), Participation, Responsibility and Choice, Amsterdam, Amsterdam University Press, 127-45.

North, D. C. (2005). Understanding the Process of Economic Change, Princeton, NJ, Princeton University Press.

Nunbogu, A. M. (2014). Self-organisation in informal settlements. A case study of the greater Accra metropolitan area, Ghana. University of Groningen (Masters Thesis) http://irs.ub.rug.nl/dbi/54215e0ff07dc.

Nunbogu, A.M \& Korah, P.I. (2016). Self-organisation in urban spatial planning: evidence from the Greater Accra Metropolitan Area, Ghana. Urban Research \& Practice, 1-18: doi: 10.1080/17535069.2016.1238502.

Obeng-Odoom, F. (2010). 'Abnormal' urbanisation in Africa: a dissenting view. African GeographicalReview, 29(2), 13-40.

Obstfeld, D. (2005). Social networks, the tertius iungens orientation, and involvement in innovation. Administrative science quarterly, 50(1), 100-130.

Ostrom, E. (1996). Crossing the great divide: Coproduction, synergy, and development. World Development 24: 1073-1087.

Ostrom, E. (2005), Self-governance and forest resources, In Shah, P. J. \& Maitra, V. (eds), Terracotta Reader: A Market Approach to the Environment, New Delhi, Academic Foundation, 131-54.

Owusu, G. (2011). Urban growth, globalization and access to housing in Ghana's largest metropolitan area, Accra. In 4th European conference on African studies, Uppsala (pp. 15-18).

Otte, E., \& Rousseau, R. (2002). Social network analysis: a powerful strategy, also for the information sciences. Journal of information Science, 28(6), 441-453.

Parnell, S. and Pieterse, E. (2010). The 'Right to the City': Institutional Imperatives of a Developmental State. International Journal of Urban and Regional Research, 34(1), 14662.

Pelling, M., \& High, C. (2005). Social learning and adaptation to climate change. Benfield Hazard Research Centre, Disaster Studies Working Paper, 11, 1-19.

Potts, D. (2009). The slowing of sub-Saharan Africa's urbanisation: evidence and implications for urban livelihoods. Environment and Urbanisation, 21, 253-259.

Potts, D. (2012). Whatever happened to Africa's rapid urbanisation? Counterpoint Series]. London, England: Africa Research Institute. Retrieved from http://africaresearchinstitute.org/newsite/wpcontent/uploads/2013/03/Whatev er-happened-to-Africas-rapidurbanisation.pdf.(on 21.10.17).

Pryke, S. D. (2005). Towards a social network theory of project governance. Construction Management and Economics, 23(9), 927-939.

Rauws, W. (2016). Civic initiatives in urban development: self-governance versus selforganisation in planning practice. TPR, 87 (3), doi:10.3828/tpr.2016.23.

Rauws, W. \& De Roo, G. (2016). Adaptive planning: Generating conditions for urban adaptability. Lessons from Dutch organic development strategies. Environment and Planning B: Planning and Design, 0(0), 1-23; doi: 10.1177/0265813516658886

Rauws, W. S, Cook, M. \& van Dijk, T. (2014). How to Make Development Plans Suitable for Volatile Context. Planning Practice \& Research, 29(2), 133-151.

Roy, A. (2005). Urban Informality: Toward an Epistemology of Planning. Journal of the American Planning Association, 71(2), 147-158, DOI:10.1080/01944360508976689. 
Salamon, L.M. (2001). The new governance and the tools of public action: an introduction. Fordham journal of urban law, XXVIII (5), 1611-1674.

Schatzki, T. (2002). The site of the social. A philosophical account of the constitution of social life and change (pp. 1-296). University Park: The Pennsylvania State University Press.

Sparrowe, R. T., Liden, R. C., Wayne, S. J., \& Kraimer, M. L. (2001). Social networks and the performance of individuals and groups. Academy of management journal, 44(2), 316-325.

Szreter, S., \& Woolcock, M. (2004). Health by association? Social capital, social theory, and the political economy of public health. International journal of epidemiology, 33(4), 650667.

Teisman, G., van Buuren, A., \& Gerrits, L. M. (Eds.). (2009). Managing complex governance systems. Routledge.

Termeer, C. J. A. M., Sruiver, M., Gerritsen, A. \& Huntjes, P. (2013). Integrating selfgovernance in heavily regulated policy fields: insights from a Dutch farmers' cooperative. Journal of Environmental Policy \& Planning, 15, 285-302.

Teubner, G. (2011). Societal constitutionalism without politics? A rejoinder. Social and Legal Studies, 20, 2.

Townsend, R. E. (1995). Fisheries self-governance: corporate or cooperative structures? Marine Policy, 19, 39-45.

Van Dam, R., Salverda, I., \& During, R. (2014). Strategies of citizens' initiatives in the Netherlands: connecting people and institutions. Critical Policy Studies, 8(3), 323-339.

Van der Jagt, A. P. N., Elands, B. H. M., Ambrose-Oji, B., Gerházi, E., \& Steen Møller, M. (2016). Participatory governance of urban green space: Trends and practices in the EU. Nordic Journal of Architectural Research, 28.

Van Tatenhove, J.P.M., B. Arts \& P. Leroy, (eds.) (2000). Political modernisation and the environment: the renewal of environmental policy arrangements, Kluwer Academic Publishers, Dordrecht.

Wasserman, S., \& Faust, K. (1994). Social network analysis: Methods and applications (Vol. 8). Cambridge university press.

Watson V (2014). Co-production and collaboration in planning - The difference. Planning Theory and Practice 15: 62-76.

Yeboah, E \& Shaw, D. P. (2013). Customary land tenure practices in Ghana: examining the relationship with land-use planning delivery. International Development Planning Review, 35 (1); doi:10.3828/idpr.2013.3.

Yin, R. (1994). Case study research: Design and methods. London: Sage Publications 